\title{
Sacred Space and Cultural Symbol: Cultural Exegesis of Japanese Church Architecture
}

\author{
Antonius Firmansyah \\ Sophia University, Faculty of Theology, Japan \\ a-firmansyah-2fr@sophia.ac.jp
}

\begin{abstract}
:
One of the many challenges of inculturation is cultural exegesis. Different cultures can have different understanding about the sacred expressed through their symbols. Church architecture is one of those symbolic expressions. Cultural symbols of church architecture can be interpreted merely as ornamental symbols of faith rather than an invitation for understanding the underlying context of religious experience within a particular culture. To avoid this, we need to find categories which can serve as methodological components for a proper cultural exegesis. This paper will attempt to apply three categories of nature, community, and cultural tradition as the standards to understand the sacrality of a cultural symbol. Through the application of these three categories into the architecture of Japanese church, we can find that cultural symbol embedded in church architecture serves more than as a bricolage expressing a symbolic identity of faith. Instead, it serves as a marker for cultural values being transformed through experiencing the sacred. Cultural symbols in church architecture is, thus, more about revealing the experience of divine transformation of a culture rather than its appropriation to the Christian faith.
\end{abstract}

\section{Keywords:}

inculturation, sacrality, cultural exegesis, church architecture, markers/senders of the sacred, holy emptiness, noble beauty, noble simplicity

\section{How can Cultural Symbols define Sacred Space?}

What is the sacred? How can we call a space as sacred? Jeanne Halgren Kilde proposes the category of power dynamics as a measurement 
for determining the sacredness of a place. ${ }^{1}$ There are three different powers that allow a place to be called sacred: divine power, social power, and personal power. ${ }^{2}$ These powers exercise their dynamism substantially or situationally. Divine power can make a space sacred because it is believed to be there in its substance. A person who prays within the walls that contain this divine power can experience his/her receiving it from the divine dwelling in many situational activities such as sacramental liturgies. But situational power can also come from the social power of the hierarchies operating within the walls of a church.

Richard Kieckhefer, on the other hand, regards the sacredness of a space as the interplay between its spatial dynamics, specifically centering on the aesthetic impact and symbolic resonance, which takes place during its liturgical uses. ${ }^{3}$ This interplay stimulates the participation of the congregation in the liturgy to reflect upon the theological meaning of that space within the whole constellation of the church's architecture.

I believe that both points of view have insights into defining a sacred space. There are places that are sacred because the power of God does exist within this space and people come to worship and to draw their strength from the power of these places, which gives authority also to the hierarchical power exercised within their boundaries. Lourdes and other famous places of divine apparitions are examples of such places. But there are also places, or churches, which become sacred space because the dynamics of the elements of their architecture brings an understanding of the meaning of faith to believers. The hierarchical powers exercised within this dynamism of church architectural elements take on the role of an 'animator' who makes this dynamism alive and enlivens the faith of the congregation.

This is what usually happens in most church buildings. Kilde and Kieckhefer, I believe, are suggesting two ways to understand the sacred.

\footnotetext{
Jeanne Halgren Kilde, Sacred Power, Sacred Space (Oxford: Oxford University Press, 2008).

Jeanne Halgren Kilde, Sacred Power, Sacred Space, 4.

"For many theorists of religion, sacrality is a quality achieved or expressed by separation: the sacred is that which is separate from the profane, and sacred space is space behind barriers meant to restrict access, or veils meant to restrict visibility. ... a church can be marked by a sacrality not of separation but rather of association: that what makes a building sacred is not its detachment from the profane ... but the richness of its symbolic associations, its connectedness to images and narratives that bear on the deepest questions of human life." Richard Kieckhefer, Theology in Stone: Church Architecture from Byzantium to Berkeley (Oxford: Oxford University Press, 2004), 18.
} 
However, in my opinion, Kieckhefer poses a perspective which illustrates the problem that most of today's congregations are actually facing. Kieckhefer states the aim of his work as answering the question: "how does sustained exposure to a building and its markers of sacrality lead to deeper and richer understanding?" Congregation members can relate to this question because they want to have a convincingly authentic experience of the presence of the sacred in the church. Following Kieckhefer, it is essential that we first understand the nature of these "markers of sacrality" embedded within church buildings.

\section{The Relationship between Cultural Symbol and Markers of THE SACRED}

In today's postmodern world, where the celebration of multiple centers is stressed, and where cultures are liberating themselves from the domination of what once seemed to be a dominant culture, the problem of finding the sacred and finding its markers demands an interdisciplinary cultural exegesis. Multiculturalism brings with it a plurality of ways of understanding things. The postmodern view of the sacred and its markers takes into account diverse cultural views in contrast to a singular perception of the sacred.

Kieckhefer recognizes that there are markers in traditional sacramental churches such as rails and screens that function as indicators of who is allowed into the sacred space. ${ }^{5}$ He also observed that there are ethnic symbols integrated into a local church building to express its ethnic identity. ${ }^{6}$ Gerard Lukken and Mark Searle call these markers of sacrality "senders."7 They are designed to manipulate the congregation to

4 Kieckhefer, Theology in Stone ..., 10.

5 Kieckhefer, Theology in Stone ..., 31: "In short, rails and screens might serve as barriers, but they might instead be meant more as markers: as indications of distinct spaces through which (in some cases) laity as well as clergy could pass."

6 Kieckhefer, Theology in Stone ..., 212: “...these Lutheran buildings might contain markers of ethnic identity, such as the model ship suspended from the ceiling of a Danish church,”

7 “... when the faithful enter the church they genuflect. They are manipulated to do so by the sight of the tabernacle and the lamp burning beside it, which indicate the invisible presence of the eucharist... the liturgical ritual itself contains a number of actions which are governed by spatial senders: the priest's genuflecting before the tabernacle, kissing the altar, the movement from the Epistle side to the Gospel side of the altar, the movement to the pulpit to preach, ... and so on. Conjunction with the altar, the throne, the pulpit is always an expression of modal competence, while the actual concrete form assumed by these furnishings in any given instance may well add a surcharge of such semantic values as 'exclusivity' or 'authority'." Gerrard Lukken and 
act according to the differentiation between the sacred and the profane. Thus, these senders are meant to show authority and exclusivity between liturgical places and hierarchical strata among the congregation.

The markers or the senders, as shown in the traditional sacramental church, are indeed a product of a single theological paradigm. If we want to ask what is the sacred and its markers in a particular local culture, surely we must delve into that culture to find the answer. ${ }^{8}$ From a particular cultural point of view, the interplay between the sacred and its senders may not be a manipulation, because the senders may not be purposely created to identify the sacred. We cannot exclude the possibility that there might be a culture which accepts the perception of the sacred as it comes from the sender, and therefore the sender itself is sacred.

Kieckhefer has already pointed the discussion of sacred space in the right direction when he urges us to identify the markers of sacrality within church buildings. Following Kieckhefer, Kevin J. Vanhoozer further suggests that, "what makes for sacred space ultimately is not a matter of separation from the world but of association with the Word, that is with the images and narratives and symbols that have Jesus Christ as their ultimate focus." (Vanhozer: 119) This means that we can grasp the sacrality of a space when we can find the symbolic realization of the incarnate God in the cultural paradigm of that space. Thus, we should ask: how is it possible that an ethnic symbol (or markers, or senders), serves not only as a cultural identity identifier but also serves Jesus Christ, the incarnate God, as its ultimate focus, as a marker of the sacred?

\section{Categories for Interpreting the Sacred within a Culture}

The theological interpretation of culture, fundamentally depends on our interpretation of culture itself. Vanhoozer defines culture as "hardly a faith-free zone." ${ }^{9}$ Hence, he implies that the spiritual dimension of a

Mark Searle, Semiotics and Church Architecture (Den Haag: Kok Pharos Publishing House, 1993), 65 .

8 The first principle put forward by Kevin J. Vanhoozeer in his book Everyday Theology, in order to interpret a culture is stated as "try to comprehend a cultural text on its own terms ... before you "interpret" it." Kevin J. Vanhoozer, "What is Everyday Theology? How and Why Christians Should Read Culture?” ed. Kevin J. Vanhoozer, Charles A. Anderson, and Michael J. Sleasman, Everyday Theology: How to Read Cultural Texts and Interpret Trends (Cultural Exegesis) (Grand Rapids: Baker Academic, 2007), 59.

9 Vanhoozer,..., Everyday Theology, 33. 
culture is expressed in its products. Therefore, he encourages Christians to 'interpret' their culture. But this interpretation must be directed in order to find their faith's truth and not as a mere justification of their belief. ${ }^{10}$ The Church (with a capital 'c') is a cultural agent that is called to become a "witness to the truth of the gospel by participating in God's building project, realizing the well-wrought world redeemed in Christ." (Vanhoozer: 55)

In Everyday Theology, Premkumar D. Williams, also mentions that church buildings are witnesses to the need to interpret culture by Christians. This is because the Christians themselves are embedded in the power of their culture while building God's kingdom. Williams proposes three initial questions for understanding the signs embedded in church buildings in order to grasp the notion of God's incarnation within. These questions are: "(1) What is it about the building that engages our senses of the aesthetic?" "(2) Is there a sense of fittingness about the way the worship is related to the building?" "(3) Is there something about the worship itself that needs to change in light of God's Word and our witness?" (Vanhoozer: 127-128)

To these questions, Williams added further points of reflection in order to translate those initial questions into a more concrete understanding on church buildings and their symbols within a particular culture. According to Williams, when considering a particular cultural sacred space, we must reflect on its relationship with the natural environment, communal tradition, and its cultural location. Regarding nature, he proposed these guiding reflections: "How does this building encourage a sense of divine providence and Christian stewardship with respect to nature? How does the building incorporate nature into the praise of God?"11

Secondly, regarding community faith tradition, he asks how do the

10 Vanhoozer,..., Everyday Theology, 40: "Christians therefore need to be honest and acknowledge that we approach cultural texts as interpreters who hold certain convictions. After all, the banner under which a theological hermeneutics of culture marches is faith seeking understanding. Yet Christian interpretation of culture must not be content with claiming only "this is how my community sees things," for any interpreter from any community can say that. The challenge, therefore, is to seek to understand culture in ways that do not simply reflect community preferences, but discloses truth."

11 Premkumar D. Williams, "Between City and Steeple: Looking at Megachurch Architecture," ed. Kevin J.Vanhoozer, Charles A. Anderson, and Michael J. Sleasman, Everyday Theology: How to Read Cultural Texts and Interpret Trends (Cultural Exegesis), 128. 
church buildings reflect and complement the practices of theological, and communal, of Word, bread, and wine as our access to God's full presence? And, thirdly, regarding cultural location, he suggests this guiding question: "How does this building help us remember our cultural place ... in the expansion of God's kingdom? How does it speak in the language of the people, telling the culture our ancient story and indicating our citizenship in a worldwide realm?" 12

Following Vanhoozer's suggestions, I would like to place these guiding questions in a particular cultural context. Since I have been studying and working as a missionary for the past seventeen years in Japan, I have developed a certain affinity for the complex yet profound Japanese culture. The long history of evangelization in Japan has shown the value of finding a bond between faith and a culture. The Church in Japan, I believe, can provide a model to illuminate the theme of cultural symbol in sacred space.

\section{The Sacred and Its Symbol in Japanese Context}

Roland Barthes, in his book Empire of Signs, described the Japanese in a very intriguing yet precise way. Starting with Zen, which he believes is the heart of Japanese culture, Barthes observed that it is not meaning that defines the value of a symbol in Japan. Rather it is the meaninglessness that allows a Japanese symbol to speak. ${ }^{13}$ With his European background, which focused on finding the meaning to determine the value of a symbolic constellation, Barthes admitted that he could not write about Japan. Rather, he let his experiences in Japan speak for themselves to his reader. ${ }^{14}$ In this way, Barthes wanted to show that, in Japan, symbols are important not because they convey a meaning, but rather, because

${ }^{12}$ Premkumar D. Williams, Everyday Theology.

13 "Writing is after all, in its way, a satori: satori (the Zen occurrence) is more or less powerful (though in no way formal) seism which causes knowledge, or the subject to vacillate: it creates an emptiness of language. And it is also an emptiness of language which constitutes writing; it is from this emptiness that derive the features with which Zen, in the exemption from all meaning, writes gardens, gestures, houses, flower arrangements, faces, violence.” Roland Barthes, Empire of Signs (New York: Hill and Wang, 1982), 4.

14 Roland Barthes, Empire of Signs, 4: "The author has never, in any sense, photographed Japan. Rather, he has done the opposite: Japan has starred him with any number of "flashes"; or, better still, Japan has afforded him a situation of writing. This situation is the very one in which a certain disturbance of the person occurs, a subversion of earlier readings, a shock of meaning lacerated, extenuated to the point of its irreplaceable void, without the object's ever ceasing to be significant, desirable." 
they do not intend to convey any certain meaning. What they want to express is emptiness. The emptiness that Japanese symbols contain is what allows these symbols to create room for the fresh and unexpected 'illumination', the existence of a new otherness. Paradoxically, this emptiness keeps the meaning of the symbol alive.

Barthes shows the richness of this emptiness of symbolism by way of commenting that ikebana is not a mere art of flower arranging which constructs its meaning by building a certain constellation of flowers and branches. What ikebana symbolizes is that which is built by the movement of air moving among the flowers and the branches. There are no meanings built by the "finally made" ikebana. There are only hand movements when the arranger cuts the unnecessary branches, letting the air flow through spaces that are created from it, and allowing the naturalness of the tree to come to life. And by this naturalness, I mean that it is the character of a tree to let its unnecessary branches wither, to die in order to grow new ones. Ikebana does not express a certain meaning produced by its construction. Ikebana brings forth an emptiness of naturalness, an emptiness that brings forth the natural in the form of absence rather than presence. ${ }^{15}$

This absence is also reflected in the structure of Japan's capital. Even though Japanese cities are centered on one city as their capital, the capital itself is an empty city. It is not full of marks of civilization which express where "the values of civilization are gathered and condensed: spirituality (churches), power (offices), money (banks), merchandise (department stores), language (agoras: cafes and promenades)". (Barthes: 30) Needless to say, there are those values of civilization in Japan's capital, which make it a center. In fact, even today, the residence of the emperor is protected by moats, "forcing the traffic to make a perpetual detour". (Barthes: 32) Urban movements, then, are "the visible form of

15 Roland Barthes, Empire of Signs, 44-45: “... in a Japanese flower arrangements, "rigorously constructed" according to the language of Western aesthetic), and whatever the symbolic intentions of this construction as set forth in every guide to Japan and in every art book on the Ikebana, what is produced is the circulation of air, of which flowers, leaves, branches (words that are too botanical) are only the walls, the corridors, the baffles, delicately drawn according to the notion of a rarity which we dissociate, for our part, from nature, as if only profusion proved the natural; the Japanese bouquet has a volume; ..., you can move your body into the interstice of its branches, into the space of its stature, not in order to read it (to reads its symbolism) but to follow the trajectory of the hand which has written it: a true writing, since it produces a volume and since, forbidding our reading to be the simple decoding of a message (however loftily symbolic), it permits this reading to repeat the course of the writing's labour." 
invisibility" that "hides the sacred "nothing'". (Barthes: 32) The center itself is the "evaporated notion, subsisting here, not in order to radiate power, but to give to the entire urban movement the support of its central emptiness." (Barthes: 32) This character of the capital makes it a paradoxical center among the other cities of Japan.

Barthes depiction of Japanese cities as marked by instability symbolized in their train stations. Unlike Western cities, whose centers are characterized by markets, or cathedrals and museums as their landmarks, cities in Japan are marked by the connectedness of their stations. It is not so much about business, as the rush of the population moving from place to place that characterizes Japanese cities. Rather, it is the cities resemblance to nature that makes them different from Western cities. Japanese cities are like bushes, holding the identity of its people as branches that if collected together become the identity of bushes. Stations are like signs of the absence of these branches, a place in between which contains the identity of the cities they are connecting. It is the place where the names of the cities are withered, invoking their historical presence as villages, forming together, through an interaction of merchants (or the like), an identity of Japan as the presence in its absence. ${ }^{16}$

These characteristics are also portrayed in the streets of Japan. They are not identified by the rationality of their address because this conveys a directional system. Rather, they are identified because of their anonymity. Address "refers to a plan (by districts and blocks, in no way geometric), knowledge of which is accessible to the postman not to the visitor." (Barthes: 33) Japanese cities are indeed like bushes, which cannot be identified by a certain system of topography to locate its branches. Their location can only be found through an experience of discovering the place oneself. Writing a way to a certain space, out of nothingness, into one's own memory is what transforms this space into a place.

16 Roland Barthes, Empire of Signs, 38-42: "Dedicated to commerce, to transition, to departure, and yet kept in a unique structure, the station ... is stripped of that sacred character which ordinarily qualifies the major landmark of our cities: cathedrals, town halls, historical monuments. Here the landmark is entirely prosaic; no doubt the market is also a central site of the Western city; but in Tokyo merchandise is in a sense undone by the station's instability: an incessant departure thwarts its concentration; ... it is only the preparatory substance of the package and that the package itself is only the pass, the ticket which permits departure. Thus each district is collected in the void of its station, an empty point-of-affluence of all its occupations and its pleasures. ... Thus each name echoes, evoking the idea of a village, furnished with a population as individual as that of a tribe, whose immense city would be the bush. This sound of the place is that of history; for the signifying name here is not a memory but an anamnesis,...” 
These descriptions of Japanese cities are undoubtedly only a few examples to give us an idea of Japanese culture. There are many other aspects of Japanese culture that reveal or rather hide its cultural traits. However the nothingness or the emptiness stemming from Japanese $i k e$ bana and Japanese cities topography presented here for the sake of a discussion of the sacred and church buildings, I believe is enough to give us an introduction to an understanding of the idea of the sacred in Japanese culture.

The cultural symbols of the Japanese, as we have noted earlier, do have a spiritual dimension. Not in the sense that they remind the Japanese of their gods, but rather in the sense of a mentality of emptiness within the Japanese people. This mentality does not include the sense of the location of the divine as its essence. What it has is a reminder for the Japanese people that they are now the part of the in-between. The naturalness of nature is located in the flow of its events. As a part of this nature, the Japanese who inhabit the in-between of these movements, or the flow of this nature are reminded by their cultural symbols to wither themselves, to become emptiness and follow the course of nature. ${ }^{17}$ Inhabiting the in-between, the Japanese consider that their purpose in this world is to reach a state called satori when they are in total emptiness. ${ }^{18}$ This state is liberating because people are freed from their dubious mind, which distracts them from their naturalness, their purity. ${ }^{19}$

However, again, this 'purity' is not in the same sense of the asceticism found in western culture that is directed to find meaning. On the contrary, Japanese purity lies in the sense of suspension of meaning as explained before. Therefore, the Japanese symbols of the sacred are not meant to transfer the meaning of purity; rather they bring the state of purity to the person who is in contact with the symbol. Barthes recogniz-

17 Roland Barthes, Empire of Signs, 74: Barthes explained this total emptiness as a moment when one is wakened to the truth of Zen as appears in Japanese haiku. He said that it is not a condition of "an "illumination", of a symbolic hyperesthesia, but rather an end of language: there is a moment when language ceases (a moment obtained by dint of many exercises), and it is this echoless breach which institutes at once the truth of the Zen and the form -brief and empty- of haiku."

18 Roland Barthes, Empire of Signs, 75: Barthes describes satori as "no more than a panic suspension of language the blank which erases in us the reign of the Codes, the breach of that internal recitation which constitutes our person.”

19 Roland Barthes, Empire of Signs., 75 : “... and if this state of a-language is a liberation, it is because, ... the proliferation of secondary thoughts ... or what might be called the infinite supplement of supernumerary signifies... appears as jamming." 
es this distinction also when he speaks about bunraku (puppet theatre). When western spirituality recognizes an act of asceticism as a method to be in a closer relationship with God, it is as if God requires them to do so. Western spirituality brings God and men into the relationship of cause and effect, of the outer as the result of the inner. ${ }^{20}$ This dichotomy between inside and outside, as stated before, is different from the one we find in the Japanese dichotomy of the same category. For the Japanese, the differentiation between inside and outside plays the role as the boundary markers of what is sacred and what is profane.

Every substance within Japanese cosmology (heart/private, family/ home, community, nations) is indicated within this inside-outside category. The heart is the inside contrasted with others. One's family is the inside contrasted to the family of the others. The same goes for the other two. A movement to the inside is what brings a person to the sacred, contrasted with the outside, which brings the profane. Therefore, the Japanese symbol of the sacred is not a symbol that identifies who God is. It is a symbol that brings a movement to the inner where one can find the emptiness of nature instead of a meaning.

The realm of God, or in Japanese kami does not play a determinative role in locating the sacred space for the Japanese, because to them kami live in both the inside and the outside. Randall L. Nadeau, following Tokutaro Sakurai, comments that,

"The most basic distinction is that between the natural world (the space of productive activity) and the cosmos or heavens, which are outside the realm of manipulation and are thereby threatening and unpredictable. Kami reside in both realms, but only the kami identified by symbols of sacred orientation and physical separation (shrines, gates, etc.) are designated as part of a pure "inner" realm. Shrines to the kami of the cosmos/heavens such as Amaterasu and Susano-o serve to "domesticate" these deities and bring them into the "inner" world.

The heavens represent one "outside" world. The space beyond the seas represents another. The islands of Japan are sanctified by the kami of nature and by the creator-kami of the mythic chronicles

20 Roland Barthes, Empire of Signs, 62: "Bunraku practices neither the occultation nor the emphatic manifestation of its means; hence it rids the actor's manifestations of any whiff of the sacred and abolishes the metaphysical link the West cannot help establishing between body and soul, cause and effect, motor and machine, agent and actor, Destiny and man, God and creature.... In bunr$a k u$, the puppet has no strings.... since the puppet no longer apes the creature, man is no longer a puppet in the divinity's hands, the inside no longer commands the outside." 
(Kojiki and Nihongi). The dramatic torii at Miyajima, as well as similar off-shore gates symbolically surrounding the Japanese islands, show that Japan itself is "inner" and sacred, a closed circle isolated from the threatening and impure space beyond the seas. At the center of the circle stands Mt. Fuji, divine symbol and axis mundi of the sanctified world. And within this world are the protective kami of natural features, inhabiting the space of the productive field. The kami of the natural world are sanctifying agents for the nation as a whole, exorcising evil and purifying the land by their presence." ${ }^{21}$

Therefore, while shrine and temples are considered as sacred places because of their dedication to a certain kami which reminds us of Kilde's sacred space, the kami themselves play an outer role when it comes to talking about sacred space for the individual Japanese. This is confirmed also by the view of a leading architect in Japan, Masao Takenaka who manages to bring together the role of God and the Japanese view of emptiness when he talks about defining sacred space in the Japanese context. According to him the emptiness itself is holy, even though God is there. ${ }^{22}$

This contradicts what Lukken and Searle have noted earlier about the manipulation of the sacred performed by its symbols for the congregation. In the Japanese context, and this is also supported by Barthes, the action of a person toward the symbol is not induced or manipulated by the meaning of the symbol. If a Japanese person enters a temple or a shrine, what makes him/her enter the building is not because it has the meaning of God's presence suggested by its sacred symbol. Rather, it is because the symbol, through its silence, brings forth a state of 'moving

21 Randall L. Nadeau, "Dimensions of Sacred Space in Japanese Popular Culture," Intercultural Communication Studies, VI: 2 (1996), 110, http:/ /www.trinity.edu/org/ics/ICS.html, (accessed November 11, 2010).

22 Masao Takenaka connects this idea of emptiness with the passage from the Old Testament. He said, "A basic way to count space in north east Asia is 'ma' which literally means 'in between'. In Japanese language, the effort to divide space into certain functional rooms is called madori - to allocate the space in between.... This indicates the importance of recognizing the space in between other space. ... In the ordinary Japanese house there is the space called tokonoma which is the special place to hang the picture and to set the flower arrangement ... Similarly, there should be a holy place set apart to symbolize the encounter between time and eternity. Moses took off his shoes when he saw the burning bush since this place was the holy place where God revealed himself in the midst of the wilderness. (Exodus 3:5) We need to have a special place of holy emptiness in our church. (emphasis added)" Masao Takenaka, The Place where God Dwells: An Introduction to Church Architecture in Asia (Hong Kong: Christian Conference of Asia, 1995), 15-16. 
inside', of an emptiness, of a mystery that one is facing in his/her own life. ${ }^{23}$ This movement unites a Japanese person with the sacred space of a building with his/her own sacred space. Therefore, the function of sacred symbol in the Japanese context would be one that is characterized by unifying the other sacred spaces, both architecturally and psycho-spiritually, instead of demarcating a sacred space within a building.

\section{Cultural Symbol of Holy Emptiness Defining Sacred Space}

Following the paradigm of Masao Takenaka, we should ask: what then, is, the concrete symbol of holy emptiness for the Japanese Christians? So far, we have considered that emptiness, or naturalness is the point of their cultural symbols' relationship with the natural environment (ikebana), communal tradition (bunraku), and its cultural location (topography of Japanese cities). While these symbols direct us to the points of emptiness as their sacral state, we still need to answer: should we integrate these symbols into the Christian context? And if the answer to this first question is yes, then, the second question is: how can we integrate these symbols into church buildings?

From the point of view of inculturation, I think it is important here to mention the method of dynamic equivalence put forward by Anscar J. Chupungco. Dynamic equivalence, in contrast to creative assimilation which puts the stress on inserting a local ritual into the liturgy, is an effort in liturgical inculturation to re-express the original Christian message in a popular religious expression that has equivalent contents. The purpose is, undoubtedly, to transform both the local culture and the Church herself. Therefore, the first task at hand is to find the characteristic traits of the popular religious expression of the local people. ${ }^{24}$ The

23 This is precisely what Kevin Seasoltz mentioned as the purpose of liturgy. He said that, "The principal goal of the liturgy is an encounter with the mystery of God, an encounter that generates both insight and commitment. Liturgical celebration presupposes that the participants have some creative imagination and that they are willing and able to bridge the distance between themselves and the liturgical forms so that the symbols will enable them to experience reality in a new way." R. Kevin Seasoltz, A Sense of the Sacred:Theological Foundations of Christian Architecture and Art (New York: Continuum, 2007), 61.

24 "Inculturation should be the normal process for inserting popular religious expressions into the liturgy, and dynamic equivalence the suitable method to ensure that the content of the liturgy is duly safeguarded." Anscar J. Chupungcho, Liturgical Inculturation : Sacramentals, Religiosity, and Catechesis (Minnesota: The Liturgical Press, 1992), 125. 
main principle for this method is, in the words of Chupungco, "fidelity to the content". ${ }^{25}$

Even though, this method is generally applied to liturgical inculturation, I find that it is consistent with the norms that the Second Vatican Council issued regarding church architecture and local art as stated below.

"The Church has not adopted any particular style of art as her very own; she has admitted styles from every period according to the natural talents and circumstances of peoples, and the needs of the various rites. Thus, in the course of the centuries, she has brought into being a treasury of art which must be very carefully preserved. The art of our own days, coming from every race and region, shall also be given free scope in the Church, provided that it adorns the sacred buildings and holy rites with due reverence and honor; thereby it is enabled to contribute its own voice to that wonderful chorus of praise in honor of the Catholic faith sung by great men in times gone by." (Sacrosanctum Concilium (SC), \#123, emphasis added.)

This guidance from the Council provides us with the viewpoint of how the Church should re-express its notion of the sacred also through local art. This I believe is the answer to our first question: should we integrate cultural symbols in church buildings? Considering the guidance of the Council, the answer to this question would be affirmative only if the cultural symbol is local art that "adorns the sacred building and holy rites with due reverence and honor".

This kind of art is located, according to the guidance of the Council, in arts that "by their very nature, are oriented toward the infinite beauty of God which they attempt in some way to portray by the work of human hands; they achieve their purpose of redounding to God's praise and glory to the degree that they are directed exclusively to the single aim of turning men's minds devoutly toward God." (SC, \#122, emphasis added.) Judging from this criterion, the cultural symbols of local art can only be integrated within church architecture when they reveal God's beauty. This beauty of God revealed by the arts, is further clarified by the next paragraph of the Council documents: "Ordinaries, by the encouragement and favor they show to art which is truly sacred, should strive after noble beauty rather than mere sumptuous display." (SC, \#124,

25 J. Chupungcho, Liturgical Inculturation : Sacramentals, ..., 123. 
emphasis added.) The beauty of God that is looked for here is a noble beauty that is contrasted with a "mere sumptuous display".

Denis R. McNamara describes this beauty of God as a noble beauty in a more concrete way. According to him noble beauty is characterized when "it reveals to the human intellect through the senses something of an object's inner spiritual logic, what theologian Jacques Maritain called its ontological "secret." This very revelation is what we call Beauty." ${ }^{26}$ McNamara further concludes with a consequence for an art that has the characteristic of noble beauty: it should be "unlike a mere earthly lavishness that only draws attention to itself." 27 This view of McNamara that interprets the natural beauty demanded by the Council, I believe, is the paradigm that we are looking for in order to find local art that can be integrated into the local church buildings. The beauty of God is noble in the sense that it makes the revelation of God known to a community. However, noting this catechetical nature of sacred art, we should not forget that its aim is to turn "men's minds devoutly toward God" (SC, \#122.) In other words, the noble beauty of sacred art, along with its catechetical function should help the congregation to experience the transcendent, which Seasoltz has called an experience of "union". ${ }^{28}$ The sacred art within this noble beauty eventually will embody itself through liturgy, with the congregations' experience of the sacred. With this in mind let us return to our context, Japan.

We have already seen that Japanese cultural symbols have the potential to adorn Christian sacred buildings and holy rites with reverence and honor, because, as has been mentioned, the emptiness pointed to by Japanese cultural symbols is making its way into people's inner side, the side which the Japanese consider sacred. As such, Japanese cultural symbols are far from being ugly, but rather have the characteristic comparable to what the Council calls "noble simplicity" (SC, \#34.) when these symbols are presented within their rituals. These symbols are, without doubt, capable of generating reverence and honor toward the holy emptiness.

26 "Noble gives English its word know and finds its origin in the Latin nobilis, which itself comes from noscere, "to know." So a thing that is "noble" is in fact know-able.," Denis R. McNamara, Catholic Church Architecture and the Spirit of Liturgy (Chicago: Hillenbrand Books, 2009), 193.

27 Denis R. McNamara, Catholic Church Architecture ..., 193.

28 "As symbols, sacred art and architecture make present the transcendent; they point beyond themselves to what is other than themselves. In theological terms, they manifest the Spirit of God who is everywhere and always. Their goal is to facilitate the union of human beings with the divine." Seasoltz, 65. 
So far, we have been talking about cultural symbols of the Japanese from the perspective of Shintoism or Buddhism, which must be taken into account when we are talking about Japanese culture. Our task, now, is to consider these cultural symbols from Christian Japanese perspectives and investigate whether these symbols are capable of expressing what the Council refers to as noble beauty.

Takao Fujiki, in his introduction to the book Religious Facilities, signals the decline of Japanese spirituality, which was once the essential part of Japan's development. He noticed that for very few Japanese spiritual values are considered to be their motive for living. ${ }^{29}$ Regardless of this fact, he also comments that the construction of religious architecture in the modern era is characterized by diversity and the localized efforts to adapt spiritual reform to the changes in the times. ${ }^{30}$

Within this religious architecture, there are churches whose architecture incorporates the Japanese notion of emptiness into their modern sacred spaces. An example is the Catholic Church in Gotenba, Shizuoka (completed in 1993) which includes Japanese paper (washi) in its canopy above the congregation, "suggesting a boundary without entirely shutting out the entire world." ${ }^{31}$ The boundary suggests a movement to the inside, a place symbolized by the Japanese paper as the sacred in contrast to the outer world, while at the same time giving an opportunity for the outer world to enter through the open canopy. This shows the adaptation of a cultural symbol into the shape of the modern communal church.

29 "The Japanese have undergone various experiences as a people and a nation, and in the process there has been a progressive decline in the role and significance of religion in social life. The spiritual and physical rules of conduct called religion, that is, the observation of faith, which was once such a profound part of everyday life and provided life's very foundation, no longer regulates people's behavior, and its standards has been replaced by other norms. Today, religion is an act of investing absolute values temporarily in a special event such as the bon festival, the year end, a wedding or a funeral, and a work of religious architecture is a symbol of or a space for that act. However, for the devout who are in a small minority, this serves to make faith more pure and to reinforce the character of religious architecture.” Takao Fujiki, Religious Facilities: New Concepts in Architecture \& Design (Tokyo: Meisei Publication, 1997), 2-3.

30 Takao Fujiki, Religious Facilities: ..., 5: "In today's enormous and complex society, putting up a work of religious architecture is a localized effort, ... Now, ... religious architecture as a building type is becoming ever more diverse and may in fact force changes in the programs of religious activities."

31 These are the words of Yoshiharu Kanazawa, the architect of this church. Takao Fujiki, Religious Facilities: ..., 16. For a detailed picture of the architecture, please refer to http:/ /www.yokohama.catholic.jp/yokohama_Parish/yb_skyouku_parish_s01.html 
Another example is the Church of the Light (completed in 1989) in Osaka. Its architect, Tadao Ando, used natural sun light that enters through a cross-shaped giant slit in the wall into the internal side of the church as an expression of the human relationship to nature. The church "consists of a rectangular volume sliced through at a fifteen degree angles by a completely freestanding wall that separates the entrance from the chapel." 32 Philip Drew commented about this church that, "Through his work, Tadao Ando expresses the dual nature of existence. At the intersection of natural light and silence we become aware of 'nothingness', a void at the heart of things." 33 This church integrates sun light as the symbol of nature with the shape that identifies the Christian faith itself: the cross. This is another example of efforts to integrate cultural symbols, in this case: natural light, into church architecture.

Let me suggest here another example. The Cathedral of St. Mary (completed in 1964) in Mejiro, Tokyo, by Kenzo Tange is an example of how the traditional concept of Japanese symbols is transformed in the form of futuristic architecture. From the outside its form is one that shows eight hyperbolic parabolas rising upward while at the same time intersecting each other to form the shape of a cross in its horizontal shape. From afar the parabolas, made out of stainless steel, pour out a radiance of light which signals the character of the building as a religious building. What Tange wanted to build, actually, was a space that symbolizes a spiritual realm. ${ }^{34}$ The form of the cathedral itself actually

32 Takao Fujiki, Religious Facilities: ..., 56: For a detailed picture of the architecture, please refer to http: / /ibaraki-kasugaoka-church.jp

33 He also mentioned these interpretations of Ando's work: “Ando treats emptiness as a kind of divine fullness which is absolutely life-affirming. ... In the Church of the Light, the cross-shaped opening at one end becomes the door to the world above... Allied to light, which symbolizes the divine, the austere expression of the cross as an opening in the wall makes it a kind of communication with heaven, an opening through which a symbolic passage is possible." Philip Drew, Church on theWater Church of the Light:Tadao Ando (London: Phaidon, 1996), 8-11.

34 "One of the subjects we thought about was that of space and symbols. I have felt an interest in symbols as an important subject in architecture or in the arts and have wondered if contemporary architecture or contemporary arts have lost the symbol of the day. It may be more accurate to say I have been considering what is the symbol of the day, where the symbol reveals itself, and how the symbol is created. It was in the case of Tokyo Cathedral that we were faced with the problem of this kind. This was quite a new problem to us, the problem of how to symbolize a spiritual substance into a space by modern architectural technology." Kenzo Tange and Udo 
transforms vertically from a diamond shape (at the ground level) into a crucifix form (the top level). This vertical transformation of shape, together with the radiance of natural light reflected by the stainless steel walls signals Tange's effort to bring traditional Japan into the modern era. ${ }^{35}$

For Tange, being faithful to tradition does not necessarily involve exploiting it. What he wants to include from traditional Japanese architecture, for example is the simplicity of form, lack of ornamentation, and the integrity of the materials by not forcing material to work against nature. What he wanted to transform from the traditional is the tendency to see elegance as a point of weakness, or in Tange's words 'meaningless prettiness'. Tange wants his architecture to show strength and be compelling. Another thing he discontinued from tradition is the passivity toward reality, a mentality that according to Tange should be held responsible as the cause of elegance in Japanese culture. For this reason, we can understand why the Tokyo Cathedral seems to be lacking in elegance but full of authority in the radiance of its simple form. We can say that the Cathedral transforms traditional symbols within its modern appearance.

Tange's critique of the traditional, while at the same time adapting Japanese architecture to the reality of the modern era, reminds us of what inculturation should be. What Tange did actually was inculturate the Christian church into Japanese cultural values. Actually, all of the three examples I have mentioned so far, are examples of a direct integration of Japanese cultural symbols into a church building. The washi (Japanese paper) presenting not only a 'return to the inner' but also an acceptance of the modern world, outside of its open canopy. The light of nature in the form of a cross passing through the slit in the wall not only signals our belonging to nature but also to the fullness that comes from the divine and fills our emptiness through that light in the wall which serves as the door to the divine.

Kultermann. Kenzo Tange: Architecture and Urban Design (New York: Praeger Publisher, 1970), 243-244. For a detailed picture of the architecture please refer to http:/ / cathedral-sekiguchi.jp

35 "Only those who adopt a forward-looking attitude realize that tradition exists and is alive. It is therefore only they who can confront and overcome it. It means neither elaborating grandiose schemes for the future nor being fatefully involved with the past, but awareness that the most vital task of today is creatively to elevate both past and future." Tange on "'Creation in Present-day Architecture and the Japanese Tradition" in Robin Boyd, Kenzo Tange (New York: George Braziller, 1962), 113. 
Tange also presented a unique way of integrating Japanese cultural symbols into a church building. His way is not a direct integration but, in the words of Chupungco, a re-expression. What Tange said about building a spiritual realm through a symbolic space seems to be the reason for his objection to Japanese traditional values and their symbols that do not connect to the modern era. The need to symbolize Christianity's spiritual sphere with the spatial in the Cathedral made Tange's effort to form a secure humanity through architecture even more concrete. ${ }^{36} \mathrm{He}$ managed not only to integrate the Japanese symbols of simplicity and naturalness into the church building. He also succeeded in transforming the Japanese view of sacred emptiness into an emptiness that needs to be filled. ${ }^{37}$ Even though Tange's purpose sounds truly humanistic, it does not stop there. The application of its role as sacred art which expresses noble beauty by becoming a space for liturgy also serves its goal in facilitating us to experience the transcendent.

The three examples given here are examples of how cultural symbols can become expressions of the noble beauty of God. These are examples of how to deconstruct what McNamara calls the 'ontological secret' of cultural symbols. After we find this ontological secret, we can apply it to its equivalent Christian values while at the same time criticizing their defective value, as the re-expression of Christian faith through Christian architecture. In this manner, cultural symbols will reveal not only knowledge about the people that share the same cultural symbol. It will reveal also how God's revelation is there to save his people through the symbolic action of transforming their cultural symbols.

\section{Closing Remarks}

In this paper, I have attempted to show how it is possible that an ethnic symbol (or marker, or sender), serves more than just a cultural identity identifier. It also serves as a marker of the sacred which reveals the incarnate God as its ultimate focus. Through a hermeneutical process of cultural exegesis we can extract the theological values of a cultural symbol if we want to include it in church architecture. Utilizing

36 "How will the architectural and urban space be able to secure humanity, human meaning, and human value? I venture to say we need a symbolic approach to architecture and urban space in order to secure humanity, human meaning and human value in architecture and urban space," Kenzo Tange, and Udo Kultermann, Kenzo Tange:Architecture and Urban Design, 243.

37 Tadao Ando actually also shares this view. See footnote 33. 
the three categories of nature, community, and cultural location as the three identifying elements, the inclusion of cultural symbols to become markers of sacrality can be investigated. Eventually, we will find that cultural symbols can be markers for sacred space when they facilitate the transcendental transformation of the people belonging to that culture.

Edward Sövik states in Kieckhefer's book that a church should be modeled on the Japanese tea house. ${ }^{38}$ I wonder whether this is really the case when we are talking about integrating cultural symbol into church architecture. In fact, we will find that not all cultural symbols can be integrated as sacred art into church architecture and its liturgy. Many cultural symbols, although having their own spiritual values, may or may not be sacred art that express the noble beauty of God.

Undoubtedly, we can readily perceive that many cultural symbols in their spiritual dimension function not to demarcate the sacred, but to unify the sacredness of its possessor with God. However, we still need significant hermeneutical studies to deconstruct the theological value of a particular cultural symbol if we want to reveal its own transcendental transformation. Only then, can we consider them as sacred art within the church's architecture.

38 "In 1965 Sövik visited Japan, where he found the tea house a useful model of a structure combining the domestic with the spiritual. The tea house helped Sövikin his effort to crystalize an explicit aesthetic for the modern communal church. In the tea ceremony, he noted, the host invites four or so guests for the drinking of tea. "But the tea and the ritual which surrounds its preparation and distribution is the hinge on which turns a most serious human interaction, the establishment of community, the sharing of minds and feelings, and the reflective response to the mystery of beauty." The tea house is modest, usually about a hundred square feet. The host places a flower arrangement or some other object of beauty in an alcove, but it is the gathering of people and not this object that is the focus of attention. A garden path leads to the entrance porch; passage along this path is deemed important to the ceremony.” Kieckhefer, 125. 


\section{Bibliography}

Barthes, Roland. Empire of Signs. Translated by Richard Howard. New York: Hill and Wang, 1982.

Boyd, Robin. Kenzo Tange. New York: George Braziller, 1962.

Chupungcho, Anscar J. Liturgical Inculturation: Sacramentals, Religiosity, and Catechesis. Minnesota: The Liturgical Press, 1992.

Drew, Philip. Church on the Water Church of the Light: Tadao Ando. London: Phaidon, 1996.

Fujiki, Takao. Religious Facilities New Concepts in Architecture and Design. Tokyo: Meisei Publications, 1997.

Kieckhefer, Richard. Theology in Stone: Church Architecture from Byzantium to Berkeley. Oxford: Oxford University Press, 2004.

Kilde, Jeanne Halgren. Sacred Power, Sacred Space. Oxford: Oxford University Press, 2008.

Lukken, Gerrard, and Mark Searle. Semiotics and Church Architecture. Den Haag: Kok Pharos Publishing House, 1993.

McNamara, Denis R. Catholic Church Architecture and the Spirit of the Liturgy. Chicago: Hillenbrand Books, 2009.

Nadeau, Randall L. "Dimensions of Sacred Space in Japanese Popular Culture." in Intercultural Communication Studies. VI: 2 (1996). 110. http:// www.trinity.edu/org/ics/ICS.html, (accessed November 11, 2010).

Seasoltz, R. Kevin. A Sense of the Sacred: Theological Foundations of Christian Architecture and Art. New York: Continuum, 2005.

Takenaka, Masao. The Place Where God Dwells: An Introduction to Church Architecture in Asia. Hong Kong: Christian Conference of Asia, 1995.

Tange, Kenzo, and Udo Kultermann. Kenzo Tange: Architecture and Urban Design. New York: Praeger Publisher, 1970.

Vanhoozer, Kevin J., Charles A. Anderson, and Michael J. Sleasman, ed. Everyday Theology: How to Read Cultural Texts and Interpret Trends (Cultural Exegesis). Grand Rapids: Baker Academic, 2007. 